\title{
The Reinvention of Love in D. H. Lawrence's Women in Love
}

\author{
Jianjun Zheng \\ Foreign Language Department \\ South China Institute of Software Engineering, Guangzhou University \\ Guangzhou 510990, China \\ E-mail: georgezjj80@126.com
}

\begin{abstract}
Women in Love is interpreted as a novel of relationships between man and woman, man and nature, and mind and body. D. H. Lawrence's point of view on these relationships finds its best expression through the perspective of psychology and symbolism. It also suggests regenerating natural and inexorable relationships between man and woman, and man and nature to explore the mystery of life.
\end{abstract}

Keywords: Man and woman, Psychology, Symbolism, Characters

British literary critic F. R. Leavis in his great literary work D. H. Lawrence: Novelist tells that The Rainbow and Women in Love can prove D. H. Lawrence is one of the greatest literary artists, and Lawrence is a modern novelist and uses a lot of modern writing techniques to mode the characters. Women in Love is especially a book which "has artistic form more contrary to nature and meaningful structure". The characters in the novel are extraordinary in their personalities which are closely related to the bible and have symbolic meanings.

Women in Love is one of Lawrence's masterpieces and also one of the important novels in the $20^{\text {th }}$ century. Nevertheless, this novel is difficult to thoroughly comprehend and analyze Lawrence's art in novel writing. Another aspect is that different readers interpret it in different perspectives. Many readers try to understand it from a modernistic point of view and attach much importance to the writing styles and through which to reflect the characters and to exhibit one of the themes of the novel - the reinvention of love of the characters.

In Women in Love, Lawrence uses a different technique which is contrary to the traditional to arrange the structure of the novel so as to achieve his goal. It is true that the narrative structure of Women in Love is complicated. On the one hand, it has lucid narration technique to draw the outline of its theme; on the other hand, it has the psychological description which is unique and has profound symbolism. Perhaps it is the complex structure and unique creative writing style that aroused the interests of the critics as well as readers to study and further explore the unparalleled literary charm of D. H. Lawrence.

Women in Love is the novel of ideas. The structure and development of its characters are directly linked with the theme of the novel, and vividly expresses Lawrence's thinking about the development of modern man's civilization and his theory about the relationship between male and female. The novel abandons the traditional plot and linear narrative technique in novel writing, and chooses special scenes and stories which have profound significance. Within these seemingly fragmentary scenes and stories, there are internal links that draw the fate of characters together.

In Women in Love Lawrence adopts a kind of symmetry in dealing with the two pairs of characters who are in love and this becomes the basic thread to link the whole story together, also this is one of the major themes of the novel. Brangwen sisters: Ursula and Gudrun fall in love with Birkin and Gerald respectively at the beginning. Gerald ended his temporal sensual relationship with model Minette, and was captivated by the cold sculptor Gudrun, their relationship represents "death". (Leavis, p114) Birkin parted with Hermione and established the polarized male and female relationship finally with Ursula, and their relationship represents "live". (Leavis, p114) The relationships between the two pairs of lovers develop towards the opposite sides. In a perfect symmetry the narrative devices form an antithesis which reflects the main theme of the novel. Later Birkin and Ursula experienced the hardship and struggle both in idea and feeling, and at last achieved harmonious love. While another pair Gerald and Gudrun seem in harmony with each other but actually at variance, especially in their idea and thinking, finally ended with Gerald's death in the snow.

Lawrence is no doubt an outstanding psychological novelist, who is influenced by Sigmund Freud's psychoanalytical 
theory. In Women in Love, readers can find Lawrence widely uses psychological description to portray and analyze the characters, and that is conducive to reveal the theme - the mixed feeling of love and hate of the four characters. The "psychological pattern" (Leavis, p135) created by Lawrence is used to describe the characters and to promote the development of their relationships.

Lawrence's exploration on the psychological development of his characters is clearly seen in Women in Love. The psychology of the characters is the basic element in the novel, the subconscious mixed feeling of love and hate is like a driving force to promote the development of the novel and establish the relationship, while, in a sense, the novel becomes a kind of "psychodrama" Although influenced by Freud, Lawrence thought he shared little or nothing with Freud. His technique in expressing the psychology of the characters surpasses his contemporary writers and the traditional concept. Lawrence says:

You mustn't look in my novel for the old stable ego of the character. There is another ego, according to whose action the individual is unrecognizable and passes through, as it were, allotropic states which it needs a deeper sense than any we've been used to exercise, to discover...like as diamond and coal are the same pure single elements of carbon. The ordinary novel would trace the history of the diamond... but I say "diamond, what! This is carbon. " And any diamond might be coal or soot, and my theme is carbon. (Kirkpatrick, p708)

It is from the surface to interior and the direct portrait of the characters' psychology that Lawrence creates a peculiar psychological rhythm in his novels, so one cannot find the traditional characters and plots in Women in Love. In order to understand the unique structure of Women in Love one should penetrate into the very details of the psychological rhythm.

The theme of "life and death" determines the general psychological rhythm of the characters in Women in Love. Gerald is likened to the white moon, to the Alps, and to the Arctic snow wildness. The things that accompany him are always chilly, cold, hopeless and desperate. Gudrun is a person to control, to possess, and to exercise her own willpower. She has the negative destructive mental self-consciousness in the depth of her soul. Practically speaking, Gudrun belongs to the same group with Gerald, and their relationship represents death. While contrast to Gerald, Birkin symbolizes the natural, spontaneous life, the man alive and lived wholly as a man of integrity, the invincible life force that tries to overflow and stimulate him. While his lover Ursula is sensitive and protective, believes in true love and resents Birkin's lectures on the subject and his hope for some thing beyond. She is milder, calmer and more delicate than her sister. Together with Birkin they are in Lawrence's sense "man alive and woman alive". Besides this, all the other characters contribute to the theme and interact with the main characters to reflect the psychological movement of the main characters.

The complex interleaving and transposition compose the framework of the characters' psychology in Women in Love. We can perceive many detailed and particular psychological description in the novel. In chapter 8 Breadalby, Hermione and Birkin are walking toward the end of their relations, and Lawrence uses exquisite style of writing to manifest the tense relationship and psychological struggle between Hermione and Birkin. There are neither any inner soliloquies and quarrel nor any explicit expression of their action, but only their intuition, impulse and instinct. Hermione from time to time immerses into the depth of consciousness, and scrabbles at the edge of her mentality. Since Birkin is not willing to accept shelter Hermione provides for him, so subconsciously she bears a kind of hatred towards Birkin. Lawrence puts great emphasis on the psychological confrontation between Hermione and Birkin in their conflict. The whole chapter is based on the psychological rhythm, and is much like a psychodrama which dramatically demonstrates the psychological struggle between the characters.

Lawrence is one of the first novelists to introduce themes of psychology into his literary works. He believed that the healthy way of the individual's psychological development lay in the primacy of the life impulse, or in another term, the sexual impulse. Human sexuality is, to Lawrence, a symbol of Life Force. Through presenting psychological experience into individual human life and human relationships, and exploring the personalities of his characters, Lawrence has opened up a new territory in the writing of novel. This is clearly shown in Women in Love, and the novel is the typical of this kind of writing.

In Women in Love, Lawrence uses a great deal of symbolism. The symbols and images are unconventional and are good to the development of the theme. He is very good at drawing concrete symbols which can convey his theme from the ordinary objects in nature to characters. He also develops concrete subjects and details into small images which appear repeatedly from the beginning to the end in the novel, by doing this he succeeds in symbolically expressing and suggesting certain kind of meaning.

Generally speaking, the symbols in Women in Love can be categorized into two groups: images indicate life, vitality, hopefulness and prosperity; and images suggest coldness, hopelessness, decadence and death (Leavis, p205). Images that accompany Birkin and Ursula are linked with the first group of images. The couple tries their best to escape the black ugly misery world and react against the mechanical civilization. They usually go to the places full of flowers, 
trees and grass which suggest nature and life. Primrose, hyacinths, fir-trees, thickets of hazel, tufts of heather, all these are likely to be associated with life, vitality and hopefulness. Their relationship has a quality of comforting and soothing warmth and a hopeful promise. Images associated with Gerald and Gudrun are quite different from the former pair and represent the second group of images. Whenever Gerald and Gudrun appear on the scene, the atmosphere becomes cold, tense and ghastly. The cold, grey, remote, still water, the grey, visionary figures; Gerald's father's agony and suffering death; the deep snow-covered valley walled up by the steep precipice; the half-buried Crucifix and the cold stiff Gerald frozen to death, all of those images set up pictures of hopelessness and death. With a little carefulness, we can find that all these images appear at the time when their love affair begins, then comes to the turning point and final endings.

Critic Francis Fergusson makes such a statement about Lawrence: "by the time he reached Women in love, he was sure that he was through with the traditional novel that he no longer cared for individual character and circumstance." (Leavis, p221) Through the sentence we can infer that almost every character in Women in Love has a broader and more profound meaning than himself or herself, even their names have symbolic meanings. In the novel, the characters can be put into categories. Gerald is an efficient but ruthless coalmine owner, who suppresses his individual personality and emotion, twists the human instinct and nature and transforms modern man into mere instrument and slave machine, and he embodies the business achievement and fulfillment of the industrialism of the society. The things that accompany him are always chilly, cold, helpless and desperate. He is a symbolic figure of spiritual death and the decadent and corrupt western civilization, representing the whole set of bourgeois ethics. Contrary to Gerald, Birkin, in a real sense is a self-portrait of Lawrence, who fights against the cramping pressures of mechanized industrialism and the domination of any kind of dead formulas, is presented as a symbolic figure of human warmth, standing for the spontaneous Life Force.

In Women in Love, the theme of death, rebirth, Ruin, flood, Son of God and Christ are all allude to the Bible. All these biblical suggestions are developed into unifying and overwhelming archetypes throughout the whole novel and form the novel's framework upon which the structure of the novel organized. In order to strengthen his apocalyptic vision in Women in Love, Lawrence compares both Birkin and Gerald to Jesus Christ. Birkin acts as both destroyer and savior of the world. Through out the whole novel, almost all the death-like images and nature of the modern society is exposed by Birkin. Birkin's comparison to one of God's suggests the beginning of a new life, a new consciousness and a new world. Birkin and Ursula, turn a new page in their life, and it would, according to Lawrence, be the beginning of a new history for the humankind. Gerald's association with Jesus Christ is fulfilled at the end of the novel. It is well-know that Jesus actually has been murdered by his betrayer. But in the novel who after all has murdered Gerald? The answer is Gerald himself, the man himself is a murderer, and he is his own enemy. He has been committing a long process of suicide. His idealism, his belief in will-power, his mechanism, and his industrialism all betrays him in the long run; they have all the way been gnawing at his life-root. Therefore in this sense, Gerald is a Jesus-like figure, and much similar to Jesus Christ, his death should be taken as a resurrection and rebirth in spirit.

Lawrence feels that the most sacred thing is love, and the sacred can be realized only in the love between a man and a woman. Only in love can man restore his true emotional self. In Women in Love, Lawrence invents a love story which takes the wasteland of modern industrial society as its backdrop. The novel deals with the possible unconscious influence on human relationships, marriage and personal fulfillment. All this makes Women in Love an ever-lasting love novel for readers.

\section{References}

Kirkpatrick, D. L \& James Vinson, ed. (1979). Novelists and Prose Writers. London: Macmillan, 708.

Kirpatrick, D. L, Lawrence D. H. \& James Vinson, ed. (1979). Novelists and Prose Writers. London: Macmillan, 708.

Lawrence, D.H. (1994). Women in Love. Beijing: Foreign Languages Press.

Leavis, F. R. (1995). Lawrence and Art. Shanghai: Shanghai Art Publishing Press, 114, 135, 205, 221.

Li, Weiping. (1998). A Survey of British and American Modern Literature. Shanghai: Shanghai Foreign Language Teaching Press, 172.

Schorer, M \& Jiang Bingxian ed. (1995). Critical Essays of Lawrence. Shanghai: Shanghai Literature and Art Publishing Press, 72. 